\title{
CPI Welcomes the Summer 2019 Special Issue: “The Politics of Contemporary Education" with Paul A. Crutcher, invited Guest Editor
}

This CPI Special Issue is timely. Given current social, political and economic climates in which on the one hand, there are increasing signs of intolerance, bigotry, aggressive nationalism, insularity, xenophobia, types of mass violence and polarization in civil societies. While on the other hand, there are troubling indications of apathy, numbness and indifference to others. Furthermore, by borrowing from Indian mythology of having many arms, accordingly, on additional hands, there are positive signs at home and abroad, of civil resistance. Groups of adults, youths and individuals continue to resist and challenge publicly, the climates of ennui, indifference, disinformation, violence and the fallout from economic globalization and continuing impacts of colonization.

A few years ago, Paul Crutcher submitted an article to CPI; however, seeing the importance (explicitly/implicitly) of the issues discussed, Cecille DePass suggested that he should think seriously of becoming an invited CPI Guest Editor. Importantly too, she suggested that his paper could become the springboard for a Special Issue. Paul Crutcher, willingly accepted the generous offers. Over the following years, the Guest Editor has issued several calls for proposals, invited contributions from some well known scholars with interests in the field and finally, commissioned an artist to design the provocative, cover image.

The resultant issue is likely to stimulate considerable debate. In different ways, the contributors explicate problematic structural and systemic issues in contemporary, post-secondary educational institutions. Several contributors fearlessly highlight the changing contexts and landscapes of the North American academy. They demonstrate ways in which politics are enmeshed in the academy, and as importantly, illustrate in graphic details stakeholders responses to major structural changes in universities.

Paul Crutcher has selected for inclusion in his issue, research by well established and emerging academics, who work in universities in the USA, Canada, and Uganda. Contributors tackle such issues as the impacts of significant reforms in teacher education programs, standardization associated with high stakes testing and assessment, the decline in literacy, in its broadest sense, and attempts to control the curricula and assigned texts. As importantly, their work brings to the public agenda, the academy's strengths and limitations from insiders' perspectives and lived experiences. Whereas critiques of the academy from multiple perspectives are by no means new (e.g. Mayer, 2017; Berg and Seeber, 2016; Brownlee, 2015; Cote-Meek, 2014; Bruneau and Savage, 2002; Brand, 2018), what is new is the manner in which the contributors expertly map the ways in which the academia has adopted for example, corporatization, institutional branding, commodification and devaluation of knowledge-making activities, to name a few of the significant structural changes. As importantly, there are explicit critiques of some universities which conform with marketplace imperatives.

The time is right for change. Some academics, artists and literary individuals think that universities should strive actively, in order to co-create a different academic milieu. One which is continuously evolving. One in which academic communities foster well-tempered and balanced self-interests, yet at the same time, uphold and practice such values as respect, wellbeing, and dignity for all.

Cultural and Pedagogical Inquiry, Summer 2019, 11(2), pp. i-v

ISSN 1916-3460 (C) 2019 University of Alberta

http://ejournals.library.ualberta.ca/index.php/cpi/index 


\section{References}

Berg, M. and Seeber, B. K. (2016). The Slow professor: Challenging the Culture of Speed in the Academy. Toronto: University of Toronto Press.

Brand, D. (2018). Theory. Toronto: Alfred A. Knopf Canada.

Brownlee, J. (2015). Academia, Inc: How Corporatization is Transforming Canadian Universities. Halifax and Winnipeg: Fernwood Publishing.

Bruneau, W. and Savage, D. (2002). Counting out the Scholars: The Case against Performance Indicators in Higher Education. Toronto: James Lorimer \& Company Ltd. Publishers.

Cote-Meek, S. (2014). Colonized Classrooms: Racism, Trauma and Resistance in Post-Secondary Education. Halifax and Winnipeg: Fernwood Publishing.

Mayr, S. (2017). Dr. Edith Vane and the Hares of Crawley Hall. Toronto: Coach House Books.

\section{Future CPI publications include the following:}

In Fall 2019 (Vol. 11, No. 3), Carol Campbell, invited Guest Editor, showcases the spectacular growth of the visual and performing arts in the Caribbean region. In developing her issue, "Caribbean Pelau", Carol Campbell casts her invitational net widely, reaching as far north as Canada, parts of the USA, and south to Trinidad and Tobago.

Campbell invited Edward Baugh, the highly respected Professor Emeritus, The University of the West Indies, Mona, Jamaica to write an essay. His contribution summarizes the little known history of Edna Manley's influence on the Jamaicans who created the literature which deliberately broke colonial dominance in the English-speaking Caribbean. Generally, the issue according to Carol Campbell, "speaks to cultural infusion... a melange of sometimes exotic, often explosive flavours built around and evolved from our blend of European, African and Eastern heritages...".

In Summer 2020 (Vol. 12, No. 1), Cecille DePass, Enid Lee, Sonia Aujla Bhullar and Alleson Mason, will produce a Special Issue: "I know why the caged bird sings" (Maya Angelou). At present, the team is busy issuing the call for proposals and inviting contributions. To date, they have received an impressive number of proposals and at least two manuscripts. This issue is another collaborative spin-off from the CIESC Preconference, University of Calgary, May 2016. The international CPI issue will explore collective, familial and individual strategies of resistance and resiliency of immigrants/visible minorities in the diaspora, racialized minorities and people of colour. See Call for Submissions in this issue.

In Fall 2020 (Vol. 12, No. 2), Nicholas Ng-A-Fook, with assistance from Carol Lee (CPI, Vol. 9, No. 2, 2017) will produce an international issue on Migration. The Call for Submissions will be published in CPI, Vol. 11, No. 3, 2019. 


\section{Under discussion:}

(i) In Summer 2021 or 2022, a team of Indigenous academics will produce an international issue on Indigenous issues. It will be a follow-up issue to CPI, Vol. 10, No. 2, 2018. The Call for Submissions will be published in CPI, Vol. 11, No. 3, 2019.

(ii) In Fall 2021 or 2022, an international team will produce a Special Issue which explores the multiple roles, functions, challenges and triumphs of the literary, visual and performing arts in contemporary societies. Emphasis will be placed on explorations and analyses of educational contexts in which the arts promote and foster social justice, equity, peace, and the well-being and dignity for all of us. The Call for Submissions will be published in CPI, Vol. 11, No. 3, 2019.

(iii) Or, in 2022, the Summer and Fall issues will be devoted to critical pedagogy and social justice education. The 2 issues will draw on multiple perspectives in order to explore and analyze central issues and dilemmas associated with historical and contemporary patterns of power relationships in education (formal, non-formal and informal). The Call for Submissions will be published in CPI, Vol. 11, No. 3, 2019.

\section{CPI's Book Reviews}

Working with the CPI Book Review Committee, Kathy Sitter, CPI Book Review Editor, presents selected book reviews. Individuals willing to review books for CPI should see the Call for Book Reviewers (CPI, Vol. 9, No. 2, 2017) and contact Kathleen Sitter, CPI Book Review Editor.

Invitations and caveats: As an independent, voluntary, academic online journal, hosted by the University of Alberta Libraries, CPI welcomes contributions which expand our conceptual and theoretical horizons, and demonstrate ways in which equity, fairness and justice are conceptualized and/or practiced in education (formal, non-formal and informal).

CPI welcomes proposals to develop special issues, and to create additional e-Books in the Legacy Series, introduced in Winter 2019.

Although CPI publishes some contributions which are critical of the existing status quo, it is committed to publishing works which portray hope for a better future for all and not for a few of us. As importantly, CPI promotes the vision of a fairer, more equitable and a just world as documented in the UN Universal Declaration of Human Rights; and espoused and practiced by for example, Martin Luther King Jr., Mahatma Gandhi, Paulo Freire, Kofi Anan, Desmond Tutu, Maya Angelou, bell hooks, Vandana Shiva, to name a few.

Contributions published in CPI, do not necessarily express the perspectives and considered opinions of the CPI Editorial Board, its editors, reviewers and production team. 


\section{Reminders:}

(i) CPI invites its Editorial Board, readers and contributors to share information regarding, fairly recent research, publications and accomplishments.

(ii) CPI continues to welcome contributions from/by academics in the south and north in the fields of: literature, humanities, social sciences, arts, and of course, in education.

(iii) CPI requests that any future publication, exhibition, or performance of specific work published in the journal, kindly acknowledges its prior publication in CPI.

\section{Arrivals and Departures:}

CPI welcomes and looks forward to Nicholas Ng A-Fook's major Special Issue for Fall 2020. In June 2019, Nicholas Ng A-Fook completed a very successful term as President of the Canadian Society for the Study of Education (CSSE), (the largest academic society in Canada).

Cyril Dabydeen has published a book chapter entitled: "Home and Far Away: Remembering Rose Hall Sugar Plantation", in Lawrence Aje, Thomas Lacroix \& Judith Misrahi-Barak's (2018) edited book: Re-Imagining the Guyanas", published by Presses Universitaires de la Mediterranee. Aje et al.'s book pays tribute to Wilson Harris, the prolific Guyanese writer, whose works explored issues of colonialism and cultural identity.

Sarah Jane Moore is an independent creative artist. In 2019, Moore secured an artistic residency at the University of New South Wales, Australia. She is hosted by the School of Biological, Earth and Environmental Sciences. Sarah Jane brings an art-meets-science approach to explore the Indigenous stories surrounding the Baludarri, or the Sydney Rock Oyster. Previous research projects have explored the healing possibilities that engaging in art-making, story-building and songs led by First Peoples can bring to communities.

Tiffany Prete has published an article: "Beadwork as an Indigenous Research Paradigm", in Art/Research International: A Transdisciplinary Journal, Vol. 4, Issue 1, 2019, pp. 28-57. The article explores three major themes associated with Indigenous beadworks: namely, as acts of resistance, knowledge transmission, and thirdly, resilience. Tiffany is currently working with the Blood Reserve and the National Indian Brotherhood Organization on a funded research project which explores ways of implementing Judge Sinclair's (2015), Calls for Action, Truth and Reconciliation Commission.

At present, Enid Lee, Educational Consultant, Santa Cruz, is working with co-authors, Deborah Menkart and Margo Okazawa Rey to develop a revised, updated and expanded edition of the well known book, "Beyond Heroes and Holidays: A practical guide K-12 Anti-Racist, Multicultural Education and Staff Development".

Shibao Guo (2018) has published another edited book with Lloyd Wong entitled: "Immigration Racial and Ethnic Studies in 150 years of Canada: Retrospects and Prospects". Leiden: Brill/ Sense Publications. At the June 2019 SSHC Congress, CSSE Annual Conference, Shibao Guo completed a very successful term as President, Comparative and International Education Society of Canada (CIESC). 


\section{Departures:}

Unita Blackwell (1933-2019), Fellow of Harvard University, Kennedy School of Government, was a well known civil rights activist, Advisor to seven US presidents, and the first Black woman mayor in Mississippi (Google).

David Brion Davis (1927-2019), distinguished History professor, Yale University, and author of the trilogy which examined slavery in the Americas and Atlantic (Google).

Mavis Iona Pussey (1928-2019), Jamaican born, was an important American, abstract artist. Her works are among the permanent collections of several significant US museums (Google).

We thank the Guest Editor, Contributors, international and national External Reviewers, the Senior Journal Manager and the Desktop Publisher, for all of the work required to produce CPI's 2019 Summer issue.

Best wishes,

Cecille DePass and Ali Abdi

CPI Editors and Founders 